\title{
Destiny (not Allegory): Re-Designing Samonà's Mediterranean. An (im)Possible Mapping between the 'Masseria' and the House
}

Vincenzo Moschetti

Abstract

The world of Giuseppe Samonà is a world of profound destinies, of furrows that mark the surface of the island in order to move along the marine routes of the Mediterranean and arrive to distant places. Palermo, Naples and Venice thus seem connected by an invisible trace that links childhood gazes to his academic and professional activities. The link between historical imaginary and geographic imaginary finds an echo in the world of the invisible and of architectural composition. A world of forms that clashes with a precise construction of the landscape as succession of thresholds and remembrances, of architectural memories.

In this system the space of the house, the domestic space, is recomposed as fragment and relation of the ancient Sicilian masserie whose images and mappings persist intact in an elitarian and spiritual organism of compositional relationships. The traces unearthed by the author re-initiate an interrupted dialogue with the Sicilian territory, involving an archetypal adaptation that invests Mediterranean and Atlantic relationships in the re-founding of spatial hierarchies.

The article is to be understood as an exploratory document which, based on 'provocation' as analytic tool, leads to a possible spatial codification. A device that plays with the role of the image and of construction as premises for a narrative of the architectural project.

Keywords

percezione dell'architettura, wayfinding, università, collegi gesuiti, Alvaro Siza.

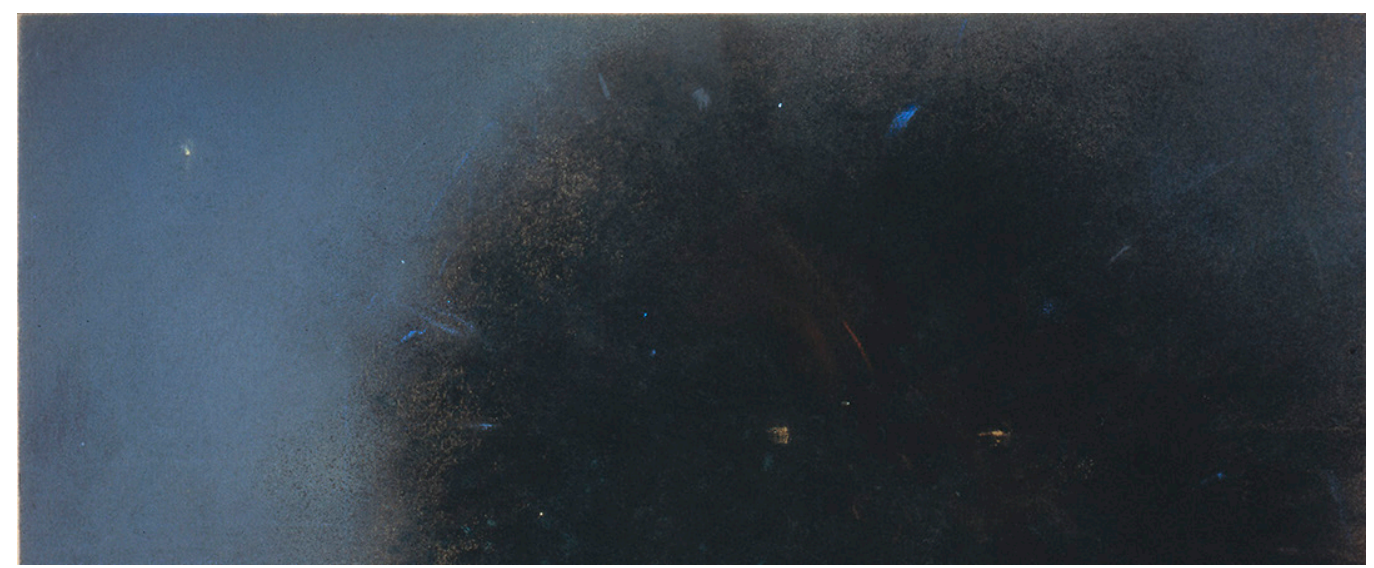




\section{The visible and the real as imaginary}

Inquiries on the visible in architecture establish narrative and theoretical premises, a sort of spiritual perception that lightly touches each boundary in which to operate and seek. Following the "trouver d'abord, chercher après" [Cocteau 2003, p. 196], the visible is seen as an unknown obviousness, as premise and palimpsest for an observation of things.

It is the gaze on the invisible that leads to the imaginary, to the point of returning to some considerations on the figure of Giuseppe Samonà within a submerged Mediterranean fabric in which facts and questions emerge regarding his architecture and the way in which he observes the world of composition [I].

The construction of this perspective is aimed "in particular to the issue of the 'locus' and of places, to the question of the historical imaginary and the geographic imaginary and of how the two together can include the exotic, the fantastic and the bizarre, which is its deformation. [...] Perhaps trying to change the world, if ever only in fragments, in order to make us forget what we cannot possess"' [Rossi 1992, Q/A 47].

This paradigm conceals the intimate meaning in which, although Samonà's architecture appears as founded on a compositional clarity, on formal and substantial data and facts, at the same time, in his experience, themes which belong to a wide geographical system seem tainted by something coming from far away.

In this sense the visible and reality, through which Samonà's spaces are revealed, tell of a tangible hierarchy which, however, conceals in the invisible and imaginary represented the genealogy of its own places; of an itinerary which took him from Palermo to Venice and of which he himself -rarely- revealed the traces.

Yet what is truly concealed in these observations? In the cold of the considerable "real marine concretions" [Semerani 1991], the suppositions return to an ontological circle in which the buildings - which for us delineate the 'facts'- represent the two elements to which the composition refers: visible/invisible, or else real/unreal, which still wholly carry out the role within the organism of representation and in the construction of the architecture project. A thought that looks to "Mediterraneity as interpretative key for transmigrations, metamor-

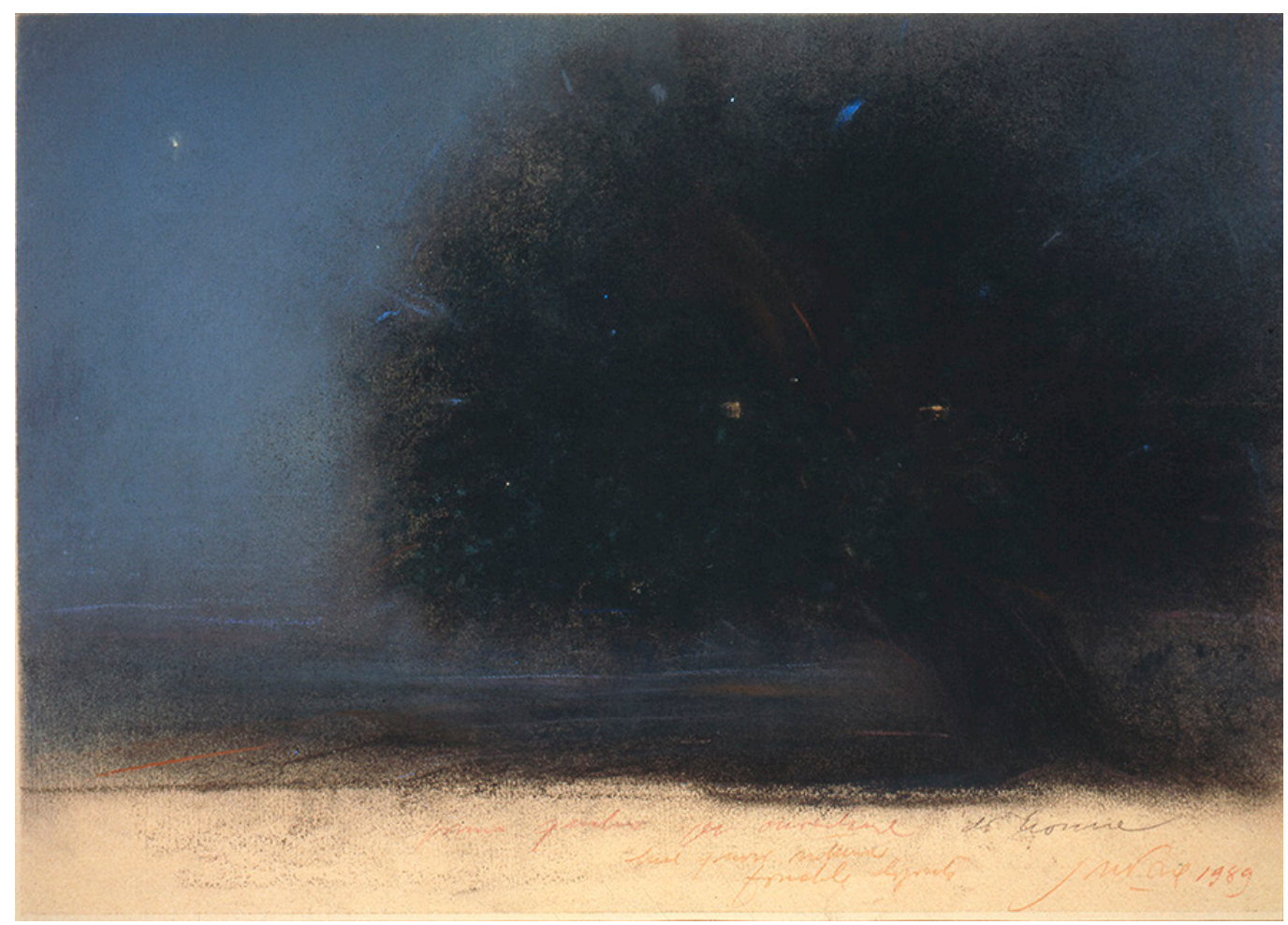


phoses, quotations of words and of ideas from one language to the other; but also [...] to a slow and not casual sedimentation" [Semerani |99|, p. 6].

Giuseppe Samonà's Mediterranean is a source that acts a priori and systematically re-founding the discourse with precision. The images of this world in which the invisible acts in an overwhelming manner on the reality of everydayness, emerge latently.

\section{Return to the earth: the masseria as paradigm, landscape as plan}

The identification of these questions emerges from the reading of the Sicilian landscape and establishes a temporal connotation of lived experiences which becomes the premise for a project in the immediacy grasped by the author. A nature that can be constructed and explored beyond Wright's studies [2], a European and non-American world which must be thus interpreted. The dialectics demonstrate how man is "configured as a plastic entity with the use of matter and in its continuity begins to signify the resolutory movement of all that is real in architecture [...] which excepts the world of nature and at the same time through building re-proposes it in its totality" [Samonà 195I].

The project of nature for Samonà is the construction of a landscape, a geometrisation of forms which finds theoretical and practical determination in the masseria. A double eye his- through which the masseria is therefore the philological paradigm which holds the gaze on the reinterpretation, translating not so much the iron-clasp typology but rather its spatial relations which are identifiable as still certain subsistence in order to address the recovery of the landscape through dwelling.

That of the masseria is "a centrality which will reveal to be non-casual but rather strongly linked to the centuries-old structuring of the territory -in which the large rural buildings constituted the elements of spatial hierarchy- : from the very ancient link to the Roman centuratio to the close relation to the infrastructural palimpsest that was defined over the past two centuries" [Pellegrino 2008, p. 9] [3]. An a priori reasoning involving the almost archaeological comparison addressed by the'landscape-related' interpretation as possible reconstruction of a microcosm, readable through a reproduction which does not change the measure of the land yet implies an eventual return to it by coming back once again to the concept of dwelling. An approach that involves repetition and the resolution of an imaginary yet accessible 'great plan' in which to relocate the project and its traits, dispositions which re-found the house by building for it the idea of a refined scenery. The path toward this recognition is described for the rooms that are the subject of a narrative which is articulated through signs, rules and conventions that are produced by way of a symbolic mediation

Fig. 2. Comparison exterior in some Venetian villas. The Palladian landscape as a pretext images taken between May and taken between May and Novifim
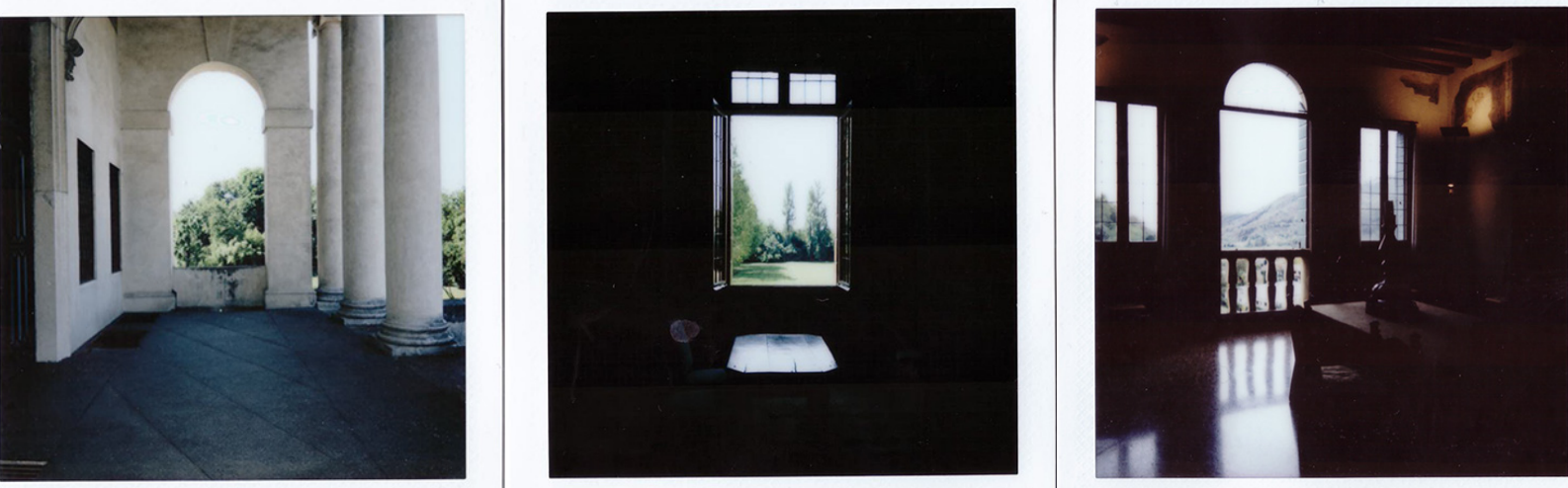
[Scelsi 20 I8] rather than by a real trace [4]. The circumscription of the relationships which remain in the territory of the masseria represent for the author a descriptive moment for the purposes of the project, an interest for what is contained rather than for what the construction is, at least formally. What remains is the tension mediated between an interior in semi-darkness and an exterior violently bathed in light in which rows of citric or olive trees appear beaten by a thick layer of slaked lime. It is in this sense that the constituting and constructing relationship is expressed, what remains of these places which through time have expressed their capacity to adaptation, to moving from factory to villa -as following a Palladian will [Cosgrove 2000] (fig. 2)- and to become the subject of spoliation, according to Samonà.

In the hands of the author remain the images, the spatial sequences, the horizontal elements and the luminous elucidation, imprinted and carved by the sun which determines closed spaces or open courtyards [Spano 1970] within which domestic everydayness takes place. The construction of the landscape thus follows a methodology that does not intervene through allegories, but rather by way of those figures specific to composition, capable of interpreting the architecture of the house as a theme expanded to the territory through the system of the plan. The desire of this deserted world "Giuseppe had carried it from life into architecture, in the elaboration and subtlety of its figures, of its details, of its sections" [Ajroldi 20 I 4, p. I0] [5], in which Sicily represents the origin of representation.

Fig. 3. Benito Spano, The protected types of the southern masseria, 1970 [Barbieri, Gambi 1970].

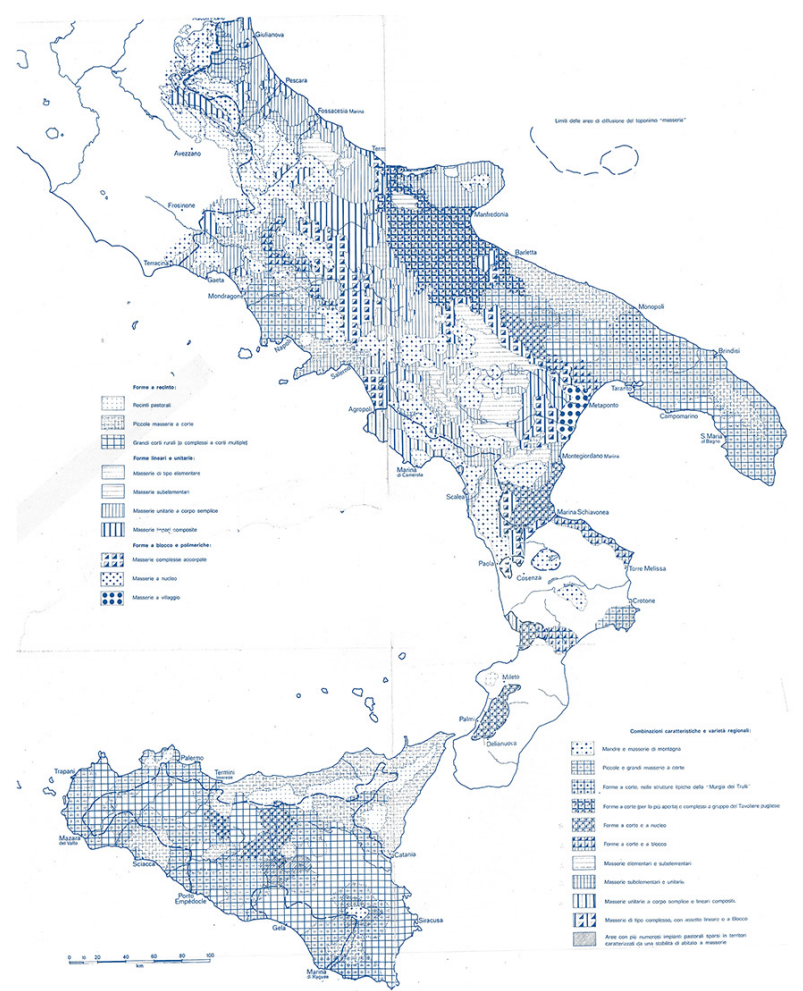

\section{The house and destiny: the how and the what}

The collection of architectural data, of images, determines to what extent 'destiny' plays a central role in this provocative identification. The integration between the domestic space (intimate) and the land (exterior) classifies the gesture of construction and leads hopes back between Palermo and Venice, in a spiritual system of places in which the island entity emerges constantly, solidifying in order to then scatter: precisely from the real to the imaginary, from the tangible to the invisible. 
Fig. 4. () Alberto Muciaccia, House in Gibilmanna, 1994

Abitare nr 376 September 998 , . 140-147.

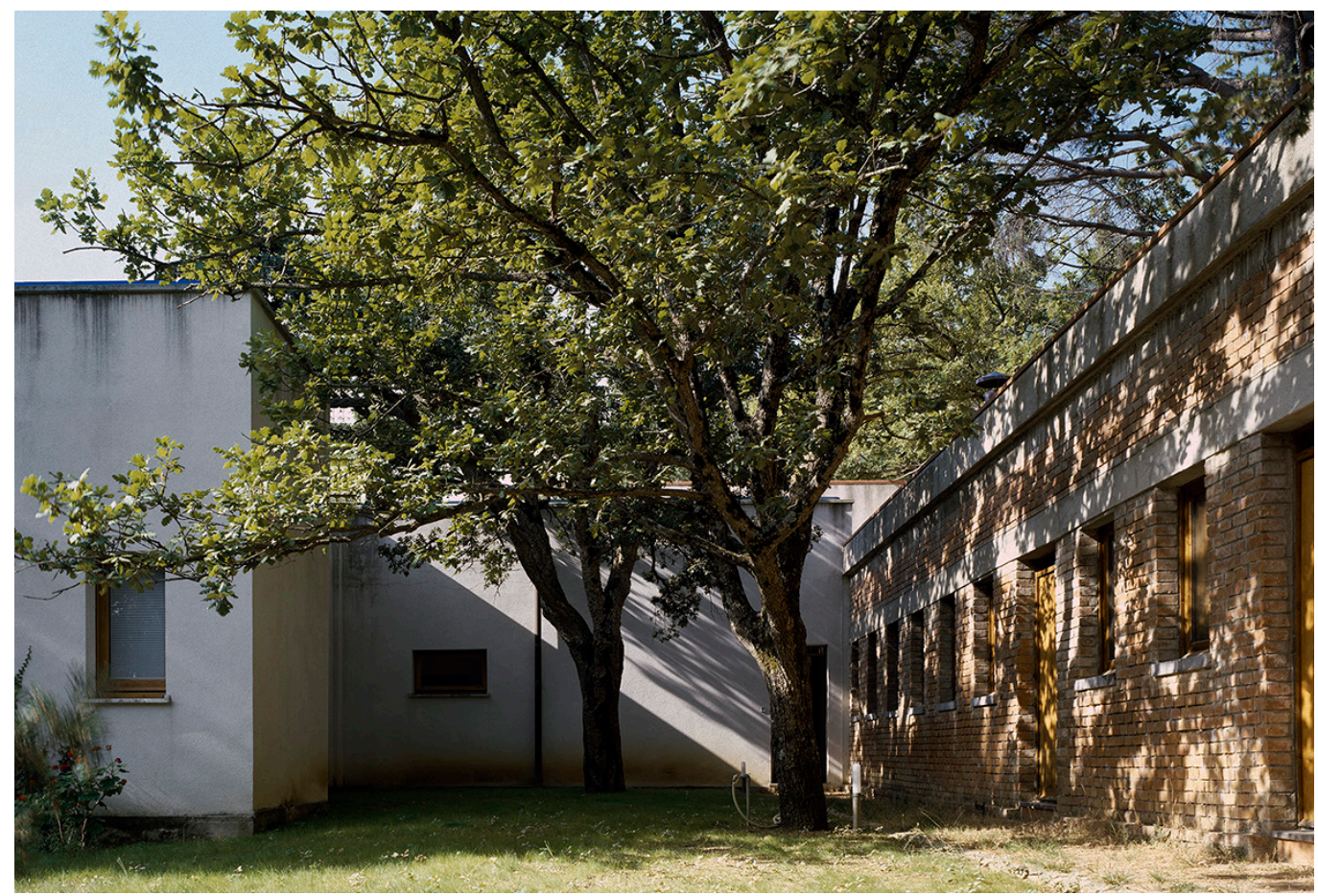

Fig. 5. (C)Alberto Muciaccia,

House in Gibilmanna

1994. Originally published

in Abitare, nr. 376,

September 1998

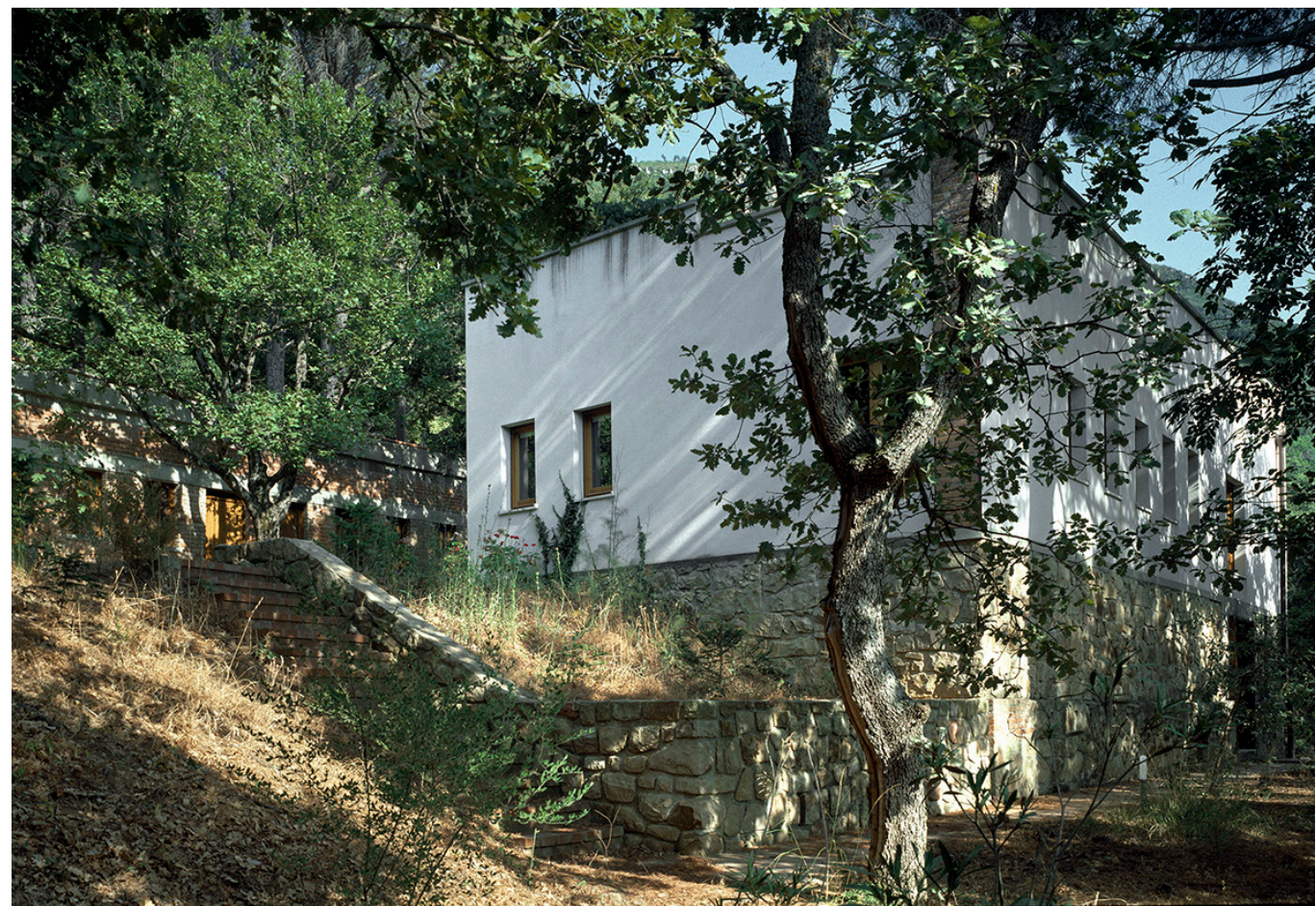


Fig. 6. Abacus of compositional relationships. Planimetric and anatomica redesign of the farm, of the Venetian type and of the house in Gibilmanna all on the same scale.
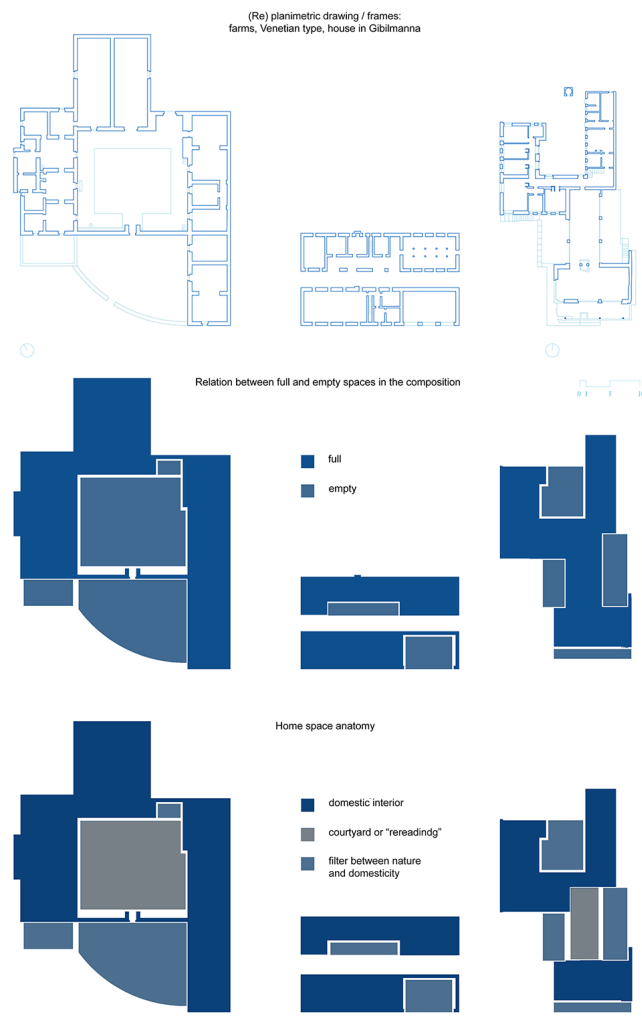

The return to the land for Samonà constitutes the choice of re-foundation, of the reinterpretation of the agricultural traces of Sicily, a verifiable concept of bauen that is represented, or perhaps presents, through the domestic meaning, of territorial circumscriptions that operate in the real tensions of construction. A score of elements in which the island, precisely, represents the experimental tabula that is then applied to an enormous, yet measurable, system of signs. The premise rooted in the studies addressed through the Gruppo Architettura gives evidence of the intention to approach the issue of the project from an infra-structural point of view. On the other hand, the analysis through which this intention is proposed is verifiable in its meaning and in the way it looks upon the territory, an observance that declares the existence of a set of relationships and wide routes that determines in substance the formal elements with which the map is constructed. Orography and architecture are united by the infrastructural meaning in which walls, bases, openings and thresholds are broken in order to determine surfaces and spaces that welcome the author into a world of compared anatomies. Although in the full formal rigor that characterizes his work, the opportunity of the single house results in a summa of great questions of content -as Semerani suggestswith the purpose of re-ordering once again, by places, a Mediterranean cartography (fig. 4). A possibility in which he declared how an actual autonomy existed [6], and in which the architectural compensation of a visible reality was determined, capable of reconstructing the landscape, if only in a fragmentary manner. In this sense "Samonà played a cunning game with the Modern Movement, opposing to it not an architecture, but rather an accumulation of questions of content" [Montuari 1988, p. 38I] [7] that highlight within the compositional language the scope and sense of becoming. Becoming is the continuation of the dialogue, from the masseria to the villa, from the villa to the house or vice versa, of the iconographic and concrete syllabary in which space is reconstructed through devices that had remained latent and were disclosed in a new configuration of places and their relationships.

The same territorial perspective is open if one observes the decisive content of the houses in Gibilmanna, the family forest, in which he devoted observations and practices to his 
brother Alberto.The continuous formal references lead to deduce to what extent the many transformations through time accumulated in the definition of spatial organisms, both in the interior and exterior, thus determining an additional condition, rather than one which is completely original.

The parts are disassembled, the pieces transferred and relocated, thus constituting a new body of the architecture of the house -influenced by his Wrightian studies- yet conscious of an invisible territorial intrusiveness, of a presence of constructive facts that establish the how and the why of the project inquiry linked to the locus.

Moving along geometrical premises, as in a land that is to be ploughed, the author defines the house by enclosures that compose a series of scenes that infiltrate the tangible nature of the forest (fig. 5). As in the villa at Baia, approximately a decade earlier than the one in Gibilmanna, the analytic process is freed from its romantic will and strives to become "reality in the real" [Pellitter 1988, p. 7] [8] in accordance with terms and notes that are capable of bringing the project closer to a wider semantic and temporal field.

The elements derived from the geographic mapping are stabilised in accordance to a new hierarchy of forms, but not of contents. Like a scientific 'toy', the masseria constitutes the beginning and the end of this house, and of this method, of its infinite translations in a mirror-like relationship. The compositional distortions are determined by the break and by the translation of scenes (or perhaps scenarios) in which the main blocks rotate to become rooms of large dimensions. The room contains in it several chambers aimed to become receptacles of experience [9], independent nuclei which are a part of a complex and probably replicable spatial structure which follows the topography and the founding agricultural system.

The recognition of the "dialogue between nature, objects and walls" [Samonà 1956], which takes place at Ronchamp, translates into signs the spatial relationships that are composed as areas of light and areas of shadow, in excavations or additions, in precise tensions that mediate luminosity -if only through the long slabs of the roof- in order to accompany the visitor along a ritual path. In all this there is the search of a substantial coherence of the space of the house that significantly transposes all the times intercepted by the constructions; identifying a continuous solution between interior and exterior and expressing once again, among the domestic walls, the idea that it may continue in harmony with the outside. A fundamentally Mediterranean deduction which is however declared and willingly placed on scene with the use of all the building techniques available to the author, as specific verification. The Mediterranean map reconstructed by Samonà in accordance with his own experiences that clash with the dream of the American prairie [I0], presupposes the miracle of duplication that permits to unite in this case an entire Venetian body [I I] with the reality of the masseria. The walls meet and are founded, they open and close, thus determining spaces, renovating the relationships in which the proposed signs create living-rooms, halls, or the more private spaces of the chambers. The sequences are the same and are configured by giving life to a new time in which the poetics of illusion transposes the contrast between the solidity of the walls of the masseria, of shadow and light, which is none other than the construction of the Mediterranean image. The effort with which the house takes possession of the terrain clarifies the idea of setting roots where it is not possible, at the place where the orography represents, through the forest, the formal spectrum: in order to translate a new compositional fact addressed through infrastructures.

Everything is closed, because the rural model of reference is closed, because in it few places open themselves to meet, to a certain extent, the Atlantic or Mitteleuropean worlds. The walls are signs that expose and conceal the domestic space, as is the responsibility of Mediterranean dwelling, fragmenting themselves and breaking into sections, however unchanging. The theme is no longer that of the cavern which subtracts mass from the earth, but rather that of the body that accumulates on the surface, establishing a new geography that is dense of passages in which the architecture constitutes the way of access and the fact of reality. The living-room, greatly illuminated, together with the dining-room, absolves the representation of the great courtyard from the demonstration of a possible typological re-founding which is capable of centripetally reassembling the other rooms. (figs. 7,8) The courtyard-hall 
Fig. 7. ()Alberto Muciaccia, House in Gibilmanna,

1994. Originally published in Abitare, nr. 376 ,

September 1998

pp. | $40-147$.

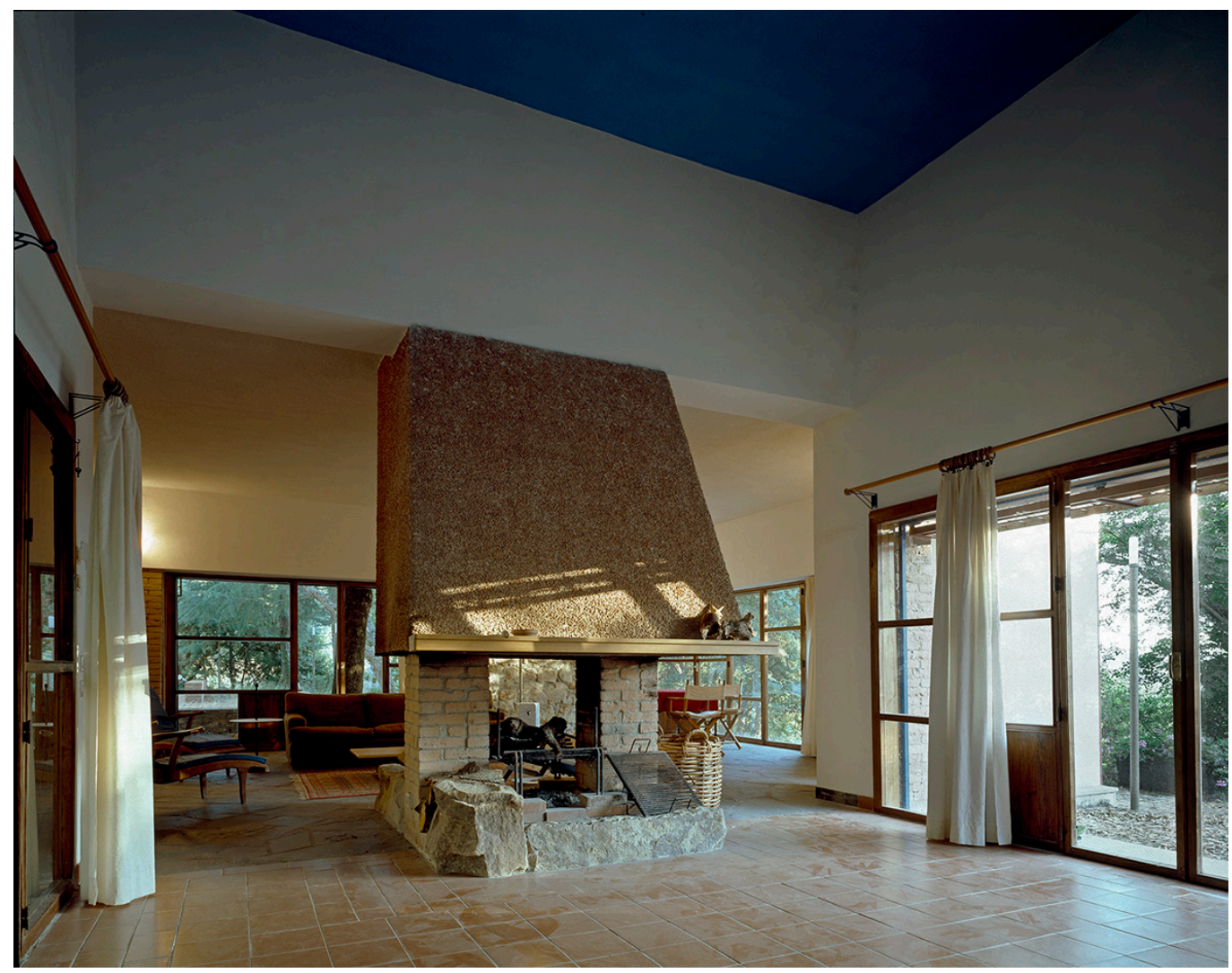

Fig. 8. ()Alberto Muciaccia, House in Gibilmanna,

1994. Originally published in Abitare, nr. 376

September 1998,

pp. | $40-147$.

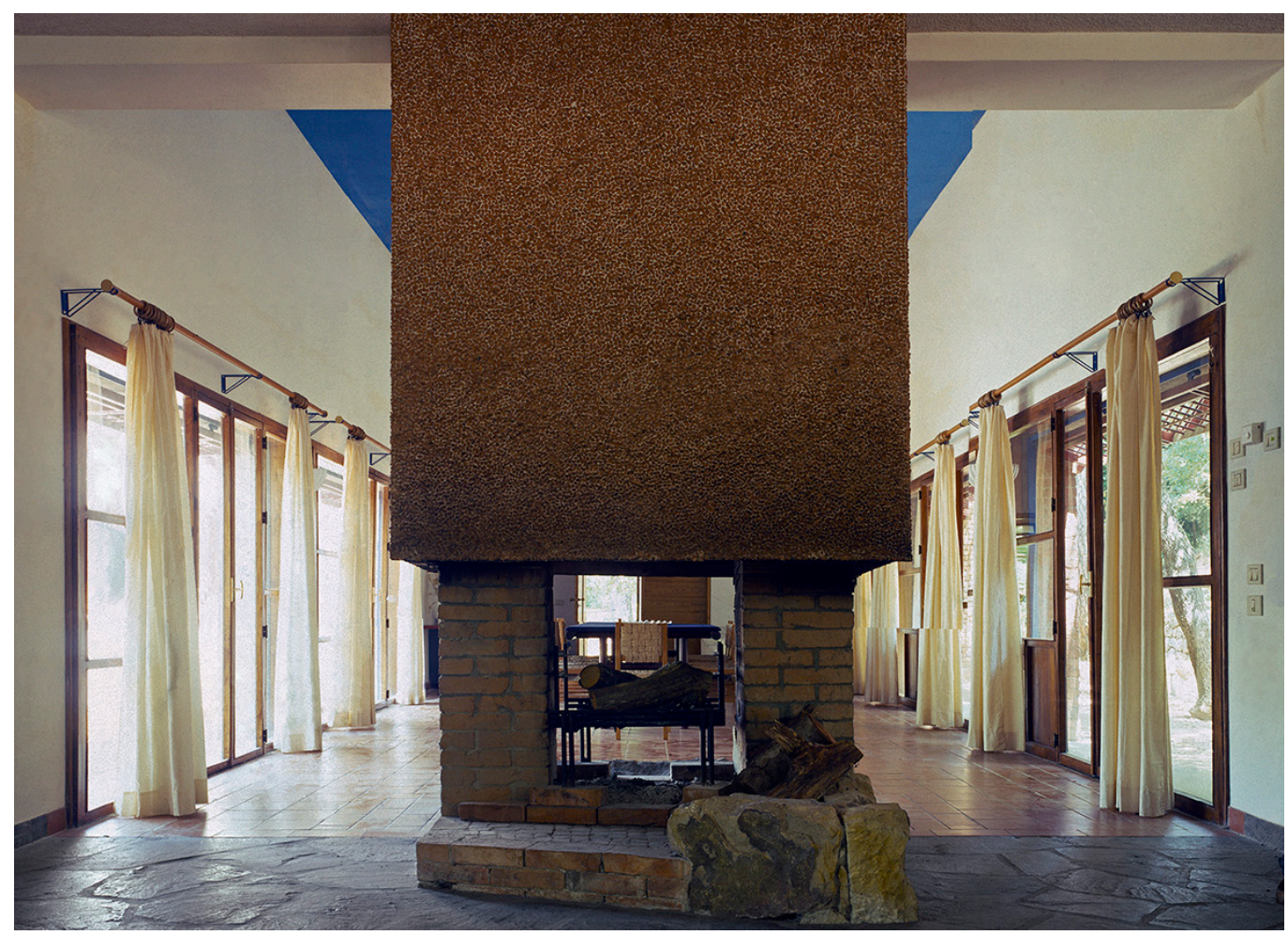


spills over into the surrounding landscape, thus amplifying its function. The order is not centrally organised but follows the natural transpositions and slippings, of the play of gazes and of the Guccionian presence of vegetation [12], object of the invisible, of a land in danger which here becomes the compositional matrix, as once were the olive trees of the fields surrounding the masseria. The trees are elements of measure and of conquest, of direct contrast through which to interpret the horizontal reading of the plan in opposition to their vertical nature. The planimetric traces on which everything is configured rise through a series of compositional episodes in which sometimes the vegetation, and other times the plasticity of the light, supported by the geometrical-agricultural prints, hold up the domestic project which appears in the manner of superimposed fragments, through extra-continental gazes; capable of following the Mediterranean routes and of joining Venice and Cefalù, if only by using a pavement made of flakes of pink marble.

Although by way of a provocative identification, useful to tone down the historiography on Samonà, the space of the masseria becomes the space of a house, reducible to parts which can be recomposed in accordance to a circularity of destinies from Palladio to Wright, in which "its transmissibility brushes against the condemnation of the unspeakable" [AA. I 975, p. 12] [13], as a result of which the possibility of the invisible appears today with tangible stupor, in other words of that which the project attempted to conceal from representation for unknown reasons.

The connection presented in this paper is the paradox of a provocative theory, not 'certified' by the literature under examination, in which only the images are open to the possibility of such a destiny, thus becoming the allegorical weaponry in a discourse with vast spatial and temporal dimensions. Beyond the theoretical apparatus, the built space highlights the problems surrounding criticism in the field of architecture.

The observations presented here, although far removed from the doctrine applied until now on Samonà the architect and designer, are intended to overturn its severity, proposing instead a Samonà-author, in other words a Samonà collector of hidden images.

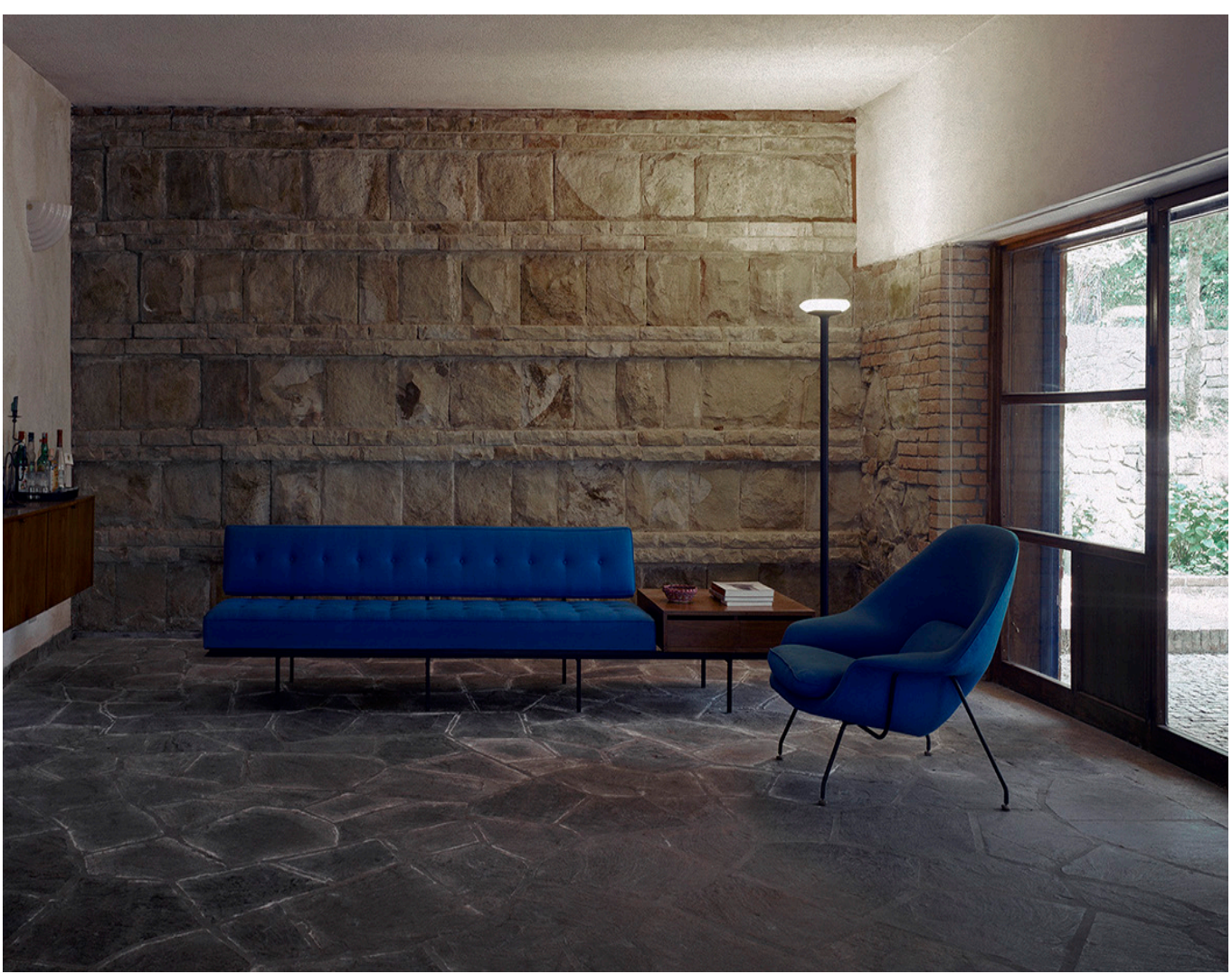


The operability of the representations highlights a parallel narrative concerning the project that is based fundamentally on the relationship between figure and backdrop, in which built architecture demonstrates the capacity to refound images by passing from a two to a three-dimensions. The resulting distortion is the offspring of a consecutio that is invisible yet actually verifiable, even if only by putting back in place the Albero del siparietto together with the entrance to the house in Gibilmanna, where a great shadow produced by plants conceals a world that lies behind it, thus becoming a paradigm for a semantic meaning that is sought between the genesis and the destiny of the built work, demonstrating the taste of conjecture with the burden of proof (fig. 10).

Fig. 10. (A) Alberto Muciaccia, House in Gibilmanna, 1994. Originally published in Abitare, nr. 376, September 1998, pp. 140-147. This image can be compared to the Albero del Siparietto by Piero Guccione.

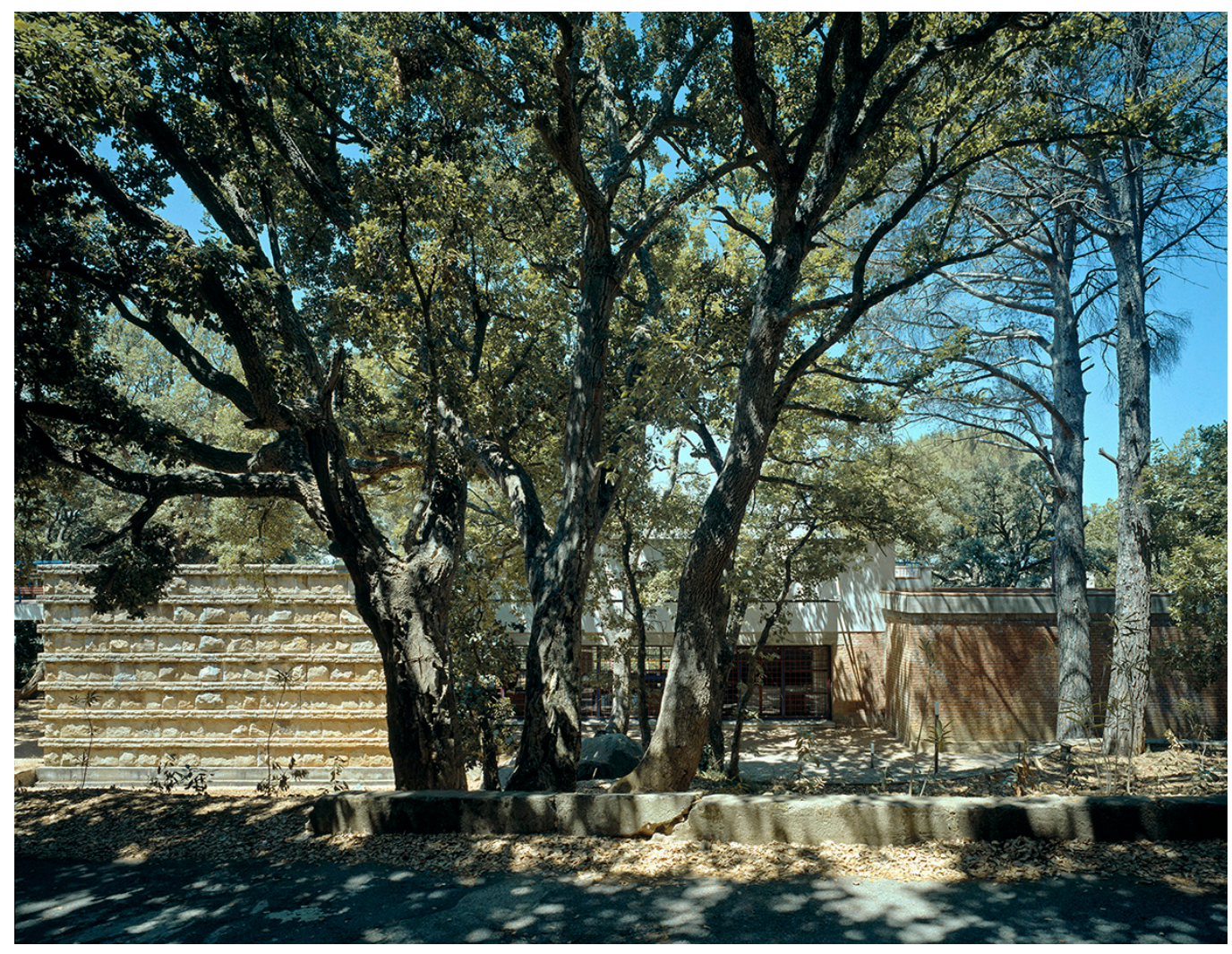

Notes

[ I] Hidden traces from Palermo and Venice, or even Naples, restore the reader to the condition in which this return to the imaginary takes place, not without some theoretical conjectures.

[2] Samonà Giuseppe (195 I). Sull'architettura di Frank Lloyd Wright. In Metron, 4I-42, May-August I95 I. Published on the occasion of the 2nd European exhibition on Frank Lloyd Wright - Palazzo Strozzi - Florence 24 June, 1951.

[3] Cantone Ugo, 2008. La casa, la città, anzi, il territorio. In Pellegrino, 2008, p. 9

[4] Not for this reason intangible.

[5]Vitale Daniele, 20 I4. Introduzione. Negli occhi punte aguzze di sole. In Ajroldi, 20 I 4, p. I0.

[6] "One thing is certain among so many arguments expressed to characterise | 4th century Sicilian architecture, and that is that it derives its greatness from a fact of civilisation indicated by a reutrn to the full coherence of taste that had been interrupted during the Suevian period, by the return, in other words, of a clear artistic unity, unique yet perfectly clear in all the most significant expressions of art [...] it is the last and very lucid glare of an affirmation of Sicilian autonomy that pervades all and that architecture expresses with a feeling that is not accidental but rather homogenously widespread" by Giuseppe Samonà, L'architettura in Sicilia dal sec. XIII a tutto il Rinascimento. In various authors, 1950. Atti del VII Congresso nazionale di storia dell'architettura (Palermo, September 1950), later included in Lovero Pasquale (ed.), 1975. L'unità architetturaurbanistica. Scritti e progetti 1929- 1973. Milan: Franco Angeli, 1975, pp. 123, 124.

[7] Semerani Luciano, 1988. Why not? In Montuori, 1988, p. 381. 
[8] Ciucci Giorgio, 1988. Presentazione. In Taormina, Pellitteri, 1988, p. 7.

[9] 'The poets of the 13th century called the essential nucleus of their poetry 'stanza', that is both 'dweling and receptacle' [Agamben 1977, p. XIII].

[10] Samonà devoted many studies to Wright's work.

$[\mathrm{II}]$ This is in reference to the proposed redesigning of the abacus (fig. 6) in the project of the house is compared to related rural buildings between southern Italy and the region of Veneto.

[12] Guccione Piero, Albero del Siparietto, 1989, Caltagirone, pastel on paper, $27 \times 38 \mathrm{~cm}$, Giuseppe lannaccone Collection.

[13] Dal Co Francesco, 1980. II gioco della memoria: 196 I - 1975. In Various Authors, 1975, p. I 12.

\section{References}

AA.W. (1975). Giuseppe Samonà. Cinquant'anni di architetture. Roma: Officina.

Agamben Giorgio (1977). Stanze. La parola e il fantasma nella cultura occidentale. Torino: Einaudi.

Ajroldi Cesare (2014). La Sicilia i sogni le città: Giuseppe Samonà e la ricerca di architettura. Padova: II Poligrafo.

Barbieri Giuseppe, Gambi Lucio (a cura di) (1970). La casa rurale in Italia. Firenze: Olschki.

Bufalino Gesualdo (1990). Saldi d'autunno. Milano: Bompiani.

Cantone Ugo (2008). La casa, la città, anzi, il territorio. In Pellegrino Luigi. Dalla masseria alla villa. Trasformazioni territoriali nell'altopiano ragusano durante il secolo XIX. Siracusa: LetteraVentidue, p. 9.

Cocteau Jean (2003). Journal d'un inconnu. Paris: Grasset.

Cosgrove Denis (2000). II paesaggio palladiano: la trasformazione geografica e le sue rappresentazioni culturali nell'Italia del XVI secolo. Sommacampagna: Cierre.

Dal Co Francesco (1980). II gioco della memoria: I96I - 1975. In AA.VV. Giuseppe Samonà. Cinquant'anni di architetture. Roma: Officina. p. 112.

Dal Co Francesco (a cura di). (1999). Aldo Rossi. I quaderni azzurri. Milano-Los Angeles: Electa-The Getty Center.

Marras Giovanni (1995). La città come testo. Teoria e poetica tra autonomia del linguaggio architettonico e figurazione della città. Venezia: IUAV, PhD Dissertation.

Montuori Marina (a cura di). (1988). Studi in onore di Giuseppe Samonà. Roma: Officina.

Panzarella Marcello (1998). Villa a Gibilmanna. In Abitare, 376, Settembre 1998, pp. I40-I47.

Pellegrino Luigi (2008). Dalla masseria alla villa. Trasformazioni territoriali nell'altopiano ragusano durante il secolo XIX. Siracusa: LetteraVentidue

Purini Franco (1989). Una casa. In Casabella, 557, Maggio 1989, p. 40-43.

Samonà Giuseppe (1950). L'architettura in Sicilia dal sec. XIII a tutto il Rinascimento. In AAVV. I950. Atti del VII Congresso nazionale di storia dell'architettura, Palermo, September 1950. (Lovero Pasquale (a cura di) (1975). L'unità architettura-urbanistica. Scritti e progetti 1929-1973. Milan: Franco Angeli, 1975, pp. 123, 124.

Samonà Giuseppe (195I). Sull'architettura di Frank Lloyd Wright. In Metron, 4I-42, May-August 195 I.

Samonà Giuseppe (1956). Lettura della Cappella di Ronchamp. L'architettura. In Cronache e storie, 8, June I 956 , p. I I 8- I 23.

Scelsi Valter (20 I 8). Opera analogica. Genoa: Sagep.

Semerani Luciano (199|). Reali concrezioni marine. In Phalaris, I6, III, p. I-6. Venezia: Marsilio.

Spano Benito (1970). La masseria meridionale. In Barbieri Giuseppe, Gambi Lucio (a cura di). La casa rurale in Italia. Firenze: Olschki.

Taormina Francesco, Pellitteri Giuseppe (a cura di). (1988). Una villa di Giuseppe Samonà. Roma: Officina.

Tomasi di Lampedusa Giuseppe (1959). Il Gattopardo. Milano: Feltrinelli.

\section{Author}

Vincenzo Moschetti, IUAV Venezia, vmoschetti@iuav.it

To cite this chapter: Moschetti Vincenzo (2020). Destiny (not allegory): re-designing Samonà's Mediterranean. An (im)possible mapping between the 'masseria' and the house. In Arena A., Arena M., Brandolino R.G., Colistra D., Ginex G., Mediati D., Nucifora S., Raffa P. (a cura di). Connettere Un disegno per annodare e tessere. Atti del $42^{\circ}$ Convegno Internazionale dei Docenti delle Discipline della Rappresentazione/Connecting. Drawing for weaving relationships. Proceedings of the 42th International Conference of Representation Disciplines Teachers. Milano: FrancoAngeli, pp. I 265- I 275. 